Mr Svetozar R. Nikitović

\title{
POMAGANJE KAO OBLIK SAUČESNIŠTVA I KAO SAMOSTALNO KRIVIČNO DELO*
}

Pre određivanja pomaganja kao oblika saučesništva neophodno je nešto reći o samom saučesništvu. Krivično delo se može izvršiti od strane jednog lica, ali pored pojedinačnog učešća u ostvarenju krivičnog dela moguće je izvršenje krivičnog dela od strane više lica koja mogu imati različite uloge u ostvarenju tog krivičnog dela. Učešće više lica u ostvarenju jednog krivičnog dela predstavlja saučesništvo, pod uslovom da su saučesnici svesni zajedničkog delovanja. Međutim, uloga više lica u jednom krivičnom delu nije ista. Neka lica se pojavljuju kao izvršioci, druga kao podstrekači, a treća kao pomagači. Treba napomenuti da u našem pozitivnom zakonodavstvu organizovanje zločinačkog udruženja ne predstavlja oblik saučesništva kao što je to bilo u ranijem zakonodavstvu.

Prema tome izvršilac ostvaruje krivično delo tj. ostvaruje sva obeležja bića određenog krivičnog dela. Bez radnje izvršenja ne bi postojalo ni pomaganje kao oblik saučesništva, jedino bi moglo postojati samostalno krivično delo pomaganja ako su ispunjeni uslovi za to. Znači da pomagač učestvuje u tuđem delu i doprinosi izvršenju takvog krivičnog dela. Radnja pomaganja je tesno vezana za radnju izvršenja i nekad je teško odvojiti je od same radnje izvršenja. Ovde treba obratiti pažnju na pojam saizvršilaštva i pojam pomaganja.

Saizvršilac je lice koje je sa umišljajem ili iz nehata preduzelo radnju izvršenja, ili je preduzelo sa umišljajem drugu radnju koja je od bitnog doprinosa za ostvarenje krivičnog dela, bez čijeg ostvarenja ne bi došlo do izvršenja krivičnog dela. Znači, za razgraničenje saizvršilaštva od pomaganja treba po-

${ }^{*}$ Rad primljen: 20. 09. 2010. 
smatrati radnju koja doprinosi izvršenju krivičnog dela, s tim što će biti radnja izvršenja ona koja je bitno doprinela izvršenju krivičnog dela dok će se raditi o radnji pomaganja kada je to radnja koja doprinosi izvršenju krivičnog dela, ali ona nije uslov za ostvarenje određenog krivičnog dela, jer bi se izvršenje krivičnog dela ostvarilo i da se umesto ove radnje pomaganja preduzela neka druga radnja (ako je na primer pomagač doneo merdevine dok je izvršilac krao a ovo krivično delo se moglo ostvariti i bez ove radnje pomaganja jer je izvršilac mogao na drugi način da omogući sebi izvršenje krivičnog dela).

Može se zaključiti da se radnja koja ne predstavlja preduzimanje radnje izvršenja smatra radnjom izvršenja ako se njom bitno doprinosi izvršenju krivičnog dela, i bez te radnje - koja može biti učinjena samo sa umišljajem određeno delo se ne bi ni ostvarilo. Druga radnja - koja predstavlja radnju pomaganja - čini onu radnju koja doprinosi izvršenju dela, ali izvršenju dela ne doprinosi bitno, jer bi se i bez preduzimanja te radnje krivično delo ostvarilo.

Pre nego se nešto konkretno kaže o pomaganju neophodno je nešto reći o pravnoj prirodi saučesništva.

\section{PRAVNA PRIRODA SAUČESNIŠTVA}

Pravna priroda saušesništva je značajna zbog odgovornosti saučesnika i njihove kažnjivosti.

O pitanju pravne prirode saučesništva postoje dve važeće teorije $\mathrm{i}$ to teorija o akcesornoj prirodi saučesništva i teorija o principalnoj odgovornosti saučesnika, pa će u daljem tekstu biti govora i o jednoj i o drugoj.

Što se tiče akcesorne prirode saučesništva, koja je važeća u našem zakonodavstvu kao i u većini stranih KZ, neophodno je reći da je to ograničena akcesornost. Ograničena akcesornost podrazumeva da odgovornost pomagača i podstrekača zavisi od onoga šta je izvršilac ostvario od krivičnog dela. Znači, da bi postojala odgovornost pomagača neophodno je da je izvršilac ostvario kažnjive pripremne radnje, ili pokušaj krivičnog dela, ili da je ostvario svršeno krivično delo. Kod ograničene akcesornosti neophodno je da izvršilac ostvari krivično delo kako je ono predviđeno u zakonu i da je to delo protivpravno. Ekstremna akcesornost koja se primenjuje u manjem broju država zahteva pored toga što je ostvareno krivično delo protivpravno i krivicu izvršioca. Zatim hiper ekstremna akcesornost koja skoro nigde nije primenjena zahteva pored krivice izvršioca, postojanje i određenih svojstava, odnosa ili okolnosti na strani izvršioca.

Prema principalnoj teoriji koliko je u jednom krivičnom delu preduzeto radnji, toliko će postojati krivičnih dela tj. svaka radnja će predstavljati samostalno krivično delo (ovo je slučaj u KZ Kraljevine Jugoslavije gde je pored svakog dela određeno kako ono predstavlja samostalno krivično delo). 
Značajno je napomenuti da se radnjom pomaganja ne ostvaruje uzrok već samo uslov posledice $u$ pitanju što proizilazi iz akcesorne prirode saučesništva.

Neka zakonodavstva su pokušavala da stepenuju koliki je doprinos pomaganja izvršenju dela. Tako imamo slučaj u Kaznitelnom zakoniku za Knjaževinu Srbiju gde je bilo predviđeno da se za pomaganje u zločinstvu za koje je bila predviđena smrtna kazna ova kazna mogla izreći pomagaču samo ako se ovo delo bez njega nije moglo ostvariti (paragraf 27. alineja 2. KZ za Knjaževinu Srbiju). Takođe stepen doprinošenja saučesništva je dosledno sproveden u KZ FNRJ od 1948. (KZ FNRJ Opšti deo).

Međutim, iako je stepen doprinošenja pomaganja u izvršenju krivičnog dela od značaja za odmeravanje kazne, noviji zakonici su odustali od stepenovanja doprinošenja saučesnika jer se nije mogao naći odgovarajući kriterijum na osnovu koga bi se odredilo koliko je doprinošenje saučesnika.

Kao pomaganje u izvršenju krivičnog dela smatraju se sledeće radnje: podupiranje tuđeg dela savetom ili uputstvom, stavljanje izvršiocu na raspolaganje sredstava za izvršenje krivičnog dela, uklanjanje prepreka za izvršenje krivičnog dela, unapred obećano prikrivanje krivičnog dela, učinioca i dr. (član. 24 KZJ).

Današnji KZ Srbije navodi samo neke od oblika pomaganja koji su najupečatljiviji kao što su: davanje saveta ili uputstava kako da se izvrši krivično delo, stavljanje učiniocu na raspolaganje sredstava za izvršenje krivičnog dela, stvaranje uslova ili otklanjanje prepreka za izvršenje krivičnog dela, kao i unapred obećano prikrivanje krivičnog dela, učinioca, sredstava kojima je krivično delo izvršeno, tragova krivičnog dela ili predmeta pribavljenih krivičnim delom (član. 35. KZ Srbije).

\section{VRSTE POMAGANJA}

Može postojati više vrsta pomaganja s obzirom na način doprinošenja $u$ izvršenju krivičnog dela od strane pomagača. Prema tome postoji: fizičko i psihičko pomaganje, pozitivno i negativno, prethodno i istovremeno, neposredno i posredno pomaganje.

Podela na fizičko i intelektualno pomaganje je izvršena prema objektivnim obeležjima pružanja pomoći. Fizičko pomaganje se moze sastojati u stavljanju na raspolaganje izvršiocu sredstava za izvršenje krivičnog dela, uklanjanju prepreka za izvršenje krivičnog dela, prikrivanju tragova, sredstava, čuvanje straže za vreme izvršenja krivičnog dela, prebacivanje učinioca na mesto izvršenja krivičnog dela. Psihičko pomaganje se sastoji u davanju saveta i uputstava, predočavanju koristi koja će se postići izvršenjem krivičnog dela, hrabrenju izvrši- 
oca da istraje u izvršenju krivičnog dela. Međutim, ako nije uspelo neposredno fizičko pomaganje može da postoji posredno psihičko pomaganje (ako jedno lice doda izvršiocu alat za obijanje da bi izvršilac ostvario krivično delo krađe, ali izvršilac ne upotrebi predmetni alat jer su vrata bila otvorena).

Postoji takođe neposredno i posredno pomaganje. Neposredno pomaganje postoji kada pomagač neposredno pomaže izvršiocu tj. direktno pomaže izvršiocu, dok kod posrednog pomaganja pomagač pomaže pomagaču - ovde se radi o indirektnom pomaganju. Međutim kod kažnjavanja pomagača nije od značaja da li se radi o neposrednom ili o posrednom pomaganju.

Postoji pozitivno i negativno pomaganje, zavisno od toga kako se preduzima radnja pomaganja. Ako se preduzima činjenjem, što je najčešći slučaj, onda je to pozitivno pomaganje, a ako se čini nečinjenjem, onda je to negativno pomaganje. Kod ovog negativnog pomaganja neophodno je da je postojala dužnost na činjenje (ako čuvar neke zgrade sazna da se sprema krađa u zgradi, pa zbog toga napusti svoje mesto).

Zatim, postoji prethodno i istovremeno pomaganje. Prethodno je ono koje se vrši pre radnje izvršenja, a istovremeno je ono koje se sprovodi u toku radnje izvršenja.

Pomaganje nije moguće posle izvršenja krivičnog dela. Međutim iako je teško utvrditi momenat okončanja krivičnog dela proizilazi da sa samim formalnim dovršenjem dela nije još prestala mogućnost pomaganja. Pomaganje je moguće do ostvarenja dela u materijalnom smislu (tj. ostvarenja zločinačke namere). Tako je pomagač onaj koji kradljivcu pomaže da odnese ukradene stvari sa mesta krađe, ili kod iznude je pomagač onaj koji iznuđenu korist donosi od žrtve iznuđivaču.

Važeći krivični zakonici prihvataju pravilo da se radi o pomaganju ako je posle izvršenja krivičnog dela došlo do pružanja pomoći izvršiocu pod uslovom da je ta pomoć obećana pre izvršenja krivičnog dela. Ovo je iz tog razloga što je time pomagač već unapred pružio potporu izvršiocu i time ga ohrabrio da izvrši krivično delo.

Poznato je postojanje sapomaganja kada više lica pruža pomaganje, ali je za postojanje ovog oblika pomaganja neophodno da svi pomagači deluju istovremeno.

Prema izloženom i sapomaganje može biti: neposredno, posredno, prethodno, istovremeno, pozitivno, negativno kao i fizičko i psihičko pomaganje.

Pomagač pomaže određeno lice u izvršenju krivičnog dela, ali pomagač ne mora da zna to lice lično a posebno ne mora znati izvršioca po imenu i prezimenu. Shodno tome, pomagač može znati da izvršilac potiče iz određenog kruga. Odnos izvršioca i pomagača je takav da izvršilac ne mora znati da mu određeno lice pruža pomoć (ako lice A čuva stražu dok lice B ubija žrtvu kazniće se kao pomagač u krivičnom delu ubistva iako lice B za tu pomoć nije znalo). 
Pomagač mora da pomaže u određenom krivičnom delu, a ne da pomaže u nekom uopštenom krivičnom delu. Pomagač treba da je svestan osnovnih elemenata konkretnog dela kao što su radnja izvršenja, posledica i uzročna veza između radnje i posledice, ali ne mora da zna mesto izvršenja krivičnog dela, ni vreme izvršenja krivičnog dela. Međutim, ako je neka od ovih činjenica bitno obeležje krivičnog dela, onda pomagač mora biti svestan i tih okolnosti.

Pojam pomaganja se određuje tako da je pomaganje umišljajno doprinošenje u izvršenju krivičnog dela određenog lica. Iz ovoga proizilazi da se pomaganje može izvršiti sa umišljajem - bilo direktnim bilo eventualnim umišljajem. Kada je namera kod krivičnih dela bitno obeležje krivičnog dela onda je neophodno da namera postoji bilo kod pomagača bilo kod izvršioca, ako ona već ne postoji kod obojice.

Što se tice kažnjivosti pomagača, neophodno je istaći da pomagač odgovara u granicama svoga umišljaja. Lične okolnosti, odnosi i svojstva uzimaju se u obzir samo kod saučesnika kod koga postoje te okolnosti, odnosi i svojstva. Predmetni odnosi, svojstva i okolnosti odnosiće se i na saučesnika kod koga ne postoje ako one predstavljaju bitna obeležja krivičnog dela.

Što se tiče postojanja pomaganja kao samostalnog dela treba napomenuti da to predstavlja odstupanje od ograničene akcesornosti i prihvatanje principalne teorije o saučesništvu. U pogledu same radnje pomaganja kao oblika saučesništva i radnje pomaganja kao samostalnog krivičnog dela, skoro da nema nikakve razlike. Međutim, razlika je u tome što se pomaganje kao oblik saučesništva pojavljuje pre ili u toku izvršenja krivičnog dela, dok se pomaganje kao samostalno krivično delo pojavljuje posle izvršenja krivičnog dela (pomoć učiniocu posle izvršenog dela). 